\title{
The Age of Studies and Reports: Selected Elements Concerning the Background of Encounters Defining the Power of Education
}

VERONIKA TAŠNER ${ }^{\star 1}$ AND SLAVKo GABER ${ }^{2}$

$\approx$ In the present paper, we discuss the time before the "age of reports". Besides the Coleman Report in the period of Coleman, the Lady Plowden Report also appeared, while there were important studies in France (Bourdieu \& Passeron, 1964; Peyre, 1959) and studies that inaugurated comprehensive education in Nordic countries. We focus on the period after the World War II, which was marked by rising economic nationalism, on the one hand, and by the second wave of mass education, on the other, bearing the promise of more equality and a reduction of several social inequalities, both supposed to be ensured by school. It was a period of great expectations related to the power of education and the rise of educational meritocracy. On this background, in the second part of the paper, the authors attempt to explore the phenomenon of the aforementioned reports, which significantly questioned the power of education and, at the same time, enabled the formation of evidence-based education policies. In this part of the paper, the central place is devoted to the case of socialist Yugoslavia/Slovenia and its striving for more equality and equity through education. Through the socialist ideology of more education for all, socialist Yugoslavia, with its exaggerated stress on the unified school and its overemphasised belief in simple equality, overstepped the line between relying on comprehensive education as an important mechanism for increasing the possibility of more equal and just education, on the one hand, and the myth of the almighty unified school capable of eradicating social inequalities, especially class inequalities, on the other. With this radical approach to the reduction of inequalities, socialist policy in the then Yugoslavia paradoxically reduced the opportunity for greater equality, and even more so for more equitable education.

Keywords: equality, equity, mass education, the age of reports, socialist Yugoslavia/ Slovenia

$1 \quad{ }^{\star}$ Corresponding Author. Faculty of Education, University of Ljubljana, Slovenia; veronika.tasner@pef.uni-lj.si.

2 Faculty of Education, University of Ljubljana, Slovenia. 


\section{Obdobje študij in poročil - izbrani elementi ozadij spoprijemov, ki določajo moč edukacije}

Veronika Tašner In SLAVko Gaber

$\propto$ V prispevku obravnavamo obdobje, ki je uvedlo čas poročil; ob Colemanovem poročilu namreč šestdeseta leta 20. stoletja zaznamujejo še poročilo Lady Plowden in nekatere pomembnejše študije družbenih neenakosti v Franciji (Bourdieu \& Passeron, 1964; Peyre, 1959) ter študije, ki so utemeljile uvajanje skupne šole v nordijskih državah. Pod drobnogled jemljemo obdobje po drugi svetovni vojni, za katero je na eni strani značilen ekonomski nacionalizem, na drugi strani pa drugi val množičnega izobraževanja, ki v sebi nosi obljubo po večji enakosti in odpravi nekaterih družbenih neenakostih, oboje pa naj bi omogočila prav šola. Gre za obdobje velikih pričakovanj, položenih v moč edukacije in uveljavljanja edukacijske meritokracije. Na izpostavljenih ozadjih v drugem delu članka poskušamo pojasniti pojav in pomen omenjenih poročil, ki so pomembna načela vere v moč edukacije, hkrati pa omogočajo snovanje na podatkih temelječe edukacijske politike. Osrednje mesto v tem delu besedila pa imajo primer socialistične Jugoslavije/ Slovenije in njena prizadevanja za dosego večje enakosti ter vprašanje pravičnosti v edukaciji. Skozi socialistično ideologijo, ki je zagovarjala več edukacije za vse, je socialistična Jugoslavija od stave na moč enotne šole oziroma od stave na preprosto enakost pričakovala preveč. Pri tem je prestopila mejo med pomenom in vlogo skupne šole, ki je sicer pomemben del mehanizma zagotavljanja enakosti in pravičnosti v edukaciji, ter mitom o moči enotne šole, ki naj bi izbrisala socialne, še posebej razredne neenakosti. $\mathrm{S}$ tem radikalnim pristopom $\mathrm{k}$ brisanju neenakosti je šolska politika v takratni Jugoslaviji po našem prepričanju paradoksalno zmanjšala možnosti za večjo enakost in pravičnost v edukaciji.

Ključne besede: enakost, pravičnost, množično izobraževanje, obdobje poročil, socialistična Jugoslavija/Slovenija 


\section{Introduction}

The contextualisation of the exceptionally fruitful wave of reflections/reconsiderations concerning the power of education in the 1960 seems logically connected to the so-called second wave of mass education, which added the demand for the best possible use of a nation's talents to the first wave's demand for basic education (e.g., Husen, 1974; Brown, 1997), ${ }^{3}$ thus bringing about an important shift in contemporary education.

Brown (1997) locates the second wave of mass education in the time after WWII, the period of so-called economic nationalism, which, through expectations connected to the slogan "more education", represents an important contribution to the changed status of education in societies. This shift is due to a combination of numerous factors: post-war reconstruction, the positioning of the state as an agent that emerged from post-war class struggles, still fresh memories related to the war horrors, the widely present fear in the West related to the spreading socialism, especially in connection with its supposed power in the field of science, etc. These and other factors in complex interrelations gave rise to the welfare state, ${ }^{4}$ which was seen as the promise of a decent life and the realisation of the growing expectations of citizens (see Gaber \& Marjanovič Umek, 2009). In general, the period between 1946 and 1973 is also, in the realm of Western civilisation, a time of rapid economic growth and rapid expansion in the field of education, combined with the promise of the well-considered government of societies. ${ }^{5}$ One of the characteristics of the period is the growing importance of technocratic and bureaucratic rationality, accompanied with and supported by technical rationality and various kinds of professionalisation (see Brown et al., 1997).

As Weber (1946) claimed, the cultivated man is not enough at the beginning of $20^{\text {th }}$ century: professionalism and the related competencies of

3 "In the post-war period education came to assume a key role in the political economy of nations, contributing to the unprecedented sense of economic and social progress that was a hallmark of the era" (Brown et al., 1997, p. 1).

4 We use the term welfare state in line with Esping-Andersen, who, in the dilemma concerning a narrower or wider concept of the welfare state, opts for a broader view, described as follows: "The broader view often frames its questions in terms of political economy, its interests focused on the state's larger role in managing and organizing the economy. In the broader view, therefore, issues of employment, wages, and overall macro-economic steering are considered integral components in the welfare-state complex. In a sense, this approach identifies its subject matter as the 'Keynesian welfare state' or, if you like, 'welfare capitalism"' (Esping-Andersen, 1996, pp. 1-2).

5 The so-called "glorious thirty", prized by many and relativised by Piketty in terms of policy dependence, actually lasted for 28 years: from 1946 to the oil crises in 1973. French demographer Jean Fourastié coined the term in 1979 with the publication of his book "The Glorious Thirty, or the Invisible Revolution from 1946 to 1975 ”. Piketty describes this period as a rapid economic "catch up" of European countries, which had fallen far behind the United States over the period 1914-1945 (...)" (Piketty, 2014, pp. 96-97). 
individuals are needed. ${ }^{6}$ The post-war period was characterised by an unprecedented development of technical rationalisation, grounded in the hierarchical division of work in the field of paid labour and in households. A similar structuring also took place in social subsystems, and thus also in and through the system of education (Brown et al., 1997). The growth of industrialisation, along with the professionalisation of production and the government of social services, drew two previously marginalised segments of the population into the field of paid work, and consequently also into education: working class people and women. Much the same can be said of working class men, who entered professions that demanded education beyond primary education. Both segments in parallel gained an opportunity for vertical mobility. With the aid of the predominant regulative idea of the time - the idea of meritocracy - members of these groups gained a range of new opportunities to change their way of life, and also for a convergence of social status, having long yearned for the symbols of the middle class.

The main impetus for the new round of development in education systems in nations across Europe thus came from the need for properly trained and educated "administrators, engineers and military personnel" (Brown et al., 1997, p. 3), i.e., for qualified workers, enabling the idea of allocating the bestsuited workers to the most demanding positions. The importance of the nation in this rearrangement did not fade away; on the contrary, under the new principle of regulation, the nation was even able to gain in importance. School, which in this "new world" took on new tasks, also became an important locus of new individual, national investments and expectations.

On this background, the possibility of a new arena of individual and social positioning meant that both individuals and societies had to develop all of their useful potentials. While the emphasis was on the potential of all members of a nation (in the nations that had been victorious in the war: USA, Great Britain, the Soviet Union, Yugoslavia, etc.), such an approach logically opened the space for the idea of equal opportunities, which had three main roles in the context of nation states: "It acts as an efficiency principle by (...) selecting and allocating

6 "Although I had been writing and speaking about space travel for years, I still have vivid memories of exactly when I heard the news. I was in Barcelona for the 8th International Astronautical Congress. We had already retired to our hotel rooms after a busy day of presentations by the time the news broke. I was awakened by reporters seeking an authoritative comment on the Soviet achievement. Our theories and speculations had suddenly become reality! For the next few days, the Barcelona Congress became the scene of much animated discussion about what the United States could do to regain some of its scientific prestige. While manned spaceflight and Moon landings were widely speculated about, many still harboured doubts about an American lead in space. One delegate, noticing that there were 23 American and five Soviet papers at the Congress, remarked that while the Americans talked a lot about spaceflight, the Russians just went ahead and did it!" (Clarke, 2007). 
individuals for the labour market on the basis of ability; it acts as a moral principal (...) and it also acts as a tool of assimilations" (Brown et al., 1997, p. 4).

To sum up, we can say that education after WWII gained a key place in the "political economies" of the respective nations. Due to the democratisation of access to education, it was an important producer of the feeling of economic and social progress and fairness that positively marked a period during which the wounds that the West had inflicted on itself in the two world wars of the century were still healing. In this context, education represented an important promise of a better world.

The educational breakthrough of the period can therefore be attributed to some degree to a fortuitous combination of a desire for the sensible regulation of conviviality between nations after unprecedented horrors, a search for avoidance of new social confrontations, and the ability to shift competition between nations from the field of warfare to the arena of knowledge and science, with their inherent innovations. In the present paper, we discuss the period in which one can observe the working of a combination of the three principles that marked thirty years of the $2 \mathrm{O}^{\text {th }}$ century: "progress, security and opportunity" (Brown et al., 1997, p. 2). These principles gained a real basis in the policies of governments, in business, in families and in education. They were brought together under the umbrella of the conceptualisation of a nation state with the power and responsibility to enable all three of them (see ibid.).

The importance and enforcement of education thus gained impetus and became part of conceptions of the conditions and benefits of economic growth, of security enabling full employment, and of opportunities for everyone who acquired an adequate education. The result was greater social security and professional mobility, which is why education is seen as the "great equalizer" (Husen, 1974, p. 7). There was a growing conviction that adequate education could provide a higher level of employment, and thus also a better future and life, for the less well-off, as well. The belief in education was high in both capitalism and socialism (Husen, 1974), both of which saw it as a solution to more than just one problem. When pointing to the prevailing type of rationality, Husen writes: "by making massive educational resources available to education one would not only boost the economic level of the individual and society at large but also solve major social problems, such as that of mass poverty" (1974, p. 7). While education was widely accepted as the "remedy" for a number of the problems of societies and individuals, parents were also more adamant in claiming an opportunity for themselves and their children. "The school was perceived as a chance for all children, not only for the elite. It was presented as an opportunity to rise to a social and professional position that was higher than the position of 
their parents" (Troger, 2002, p. 17). As a consequence of education, or in relation to education, confidence in educational meritocracy also grew.

During the first wave, secondary and tertiary education were perceived as "capital" available only to a selected few. After WWII, however, the idea emerged of education that could, with consistent care for equal opportunities for education for all, eliminate social inequalities and enable members of society to obtain an appropriate reward in the form of better status in society (Gaber, 2006). At that time, trust in education was strengthened by the combined efforts, investments and expectations of the state, teachers and parents. Meanwhile, power elites promoted education because they recognised it as a way to fully exploit the potential of their nations. With its potential to improve the position of their children, education was embraced by parents, while it is understandable that it also had the support of teachers (see Bourdieu, 1989; Meyer, 1977). As already mentioned, the idea of education for all came to forefront of education reforms, to a degree, both in capitalism and socialism. Competition exchanged the the war arena for the field of education. As such, it gained legitimacy and the future of a world with sensible aims seemed at hand. States began to compete in the fields of science, the economy, technology, etc., with competition of this kind being accepted as necessary "for motivating people" (Husen, 1974, p. 104). We did not, however, only participate in neutral "economic nationalism"; we also witnessed fierce ideological competiveness - we only have to recall the space race between the Soviet Union and the USA - but it was believed that, at the end of the day, such a race could actually lead to a higher standard of living, and was as such beneficial.

When, in the autumn of 1957, the Soviet Union gained an advantage in the space race by launching Sputnik, the USA panicked. ${ }^{7}$ The search for talent after this event became even more prominent. The best in a nation should bring that nation advantage in relation to others. After two wars, both individual and public investment in education, science and technology grew significantly. Just how crucial education seemed for a nation like the USA is indicated by the fact that one year after Sputnik they passed the National Defence Education Act.

7 "Although I had been writing and speaking about space travel for years, I still have vivid memories of exactly when I heard the news. I was in Barcelona for the $8^{\text {th }}$ International Astronautical Congress. We had already retired to our hotel rooms after a busy day of presentations by the time the news broke. I was awakened by reporters seeking an authoritative comment on the Soviet achievement. Our theories and speculations had suddenly become reality! For the next few days, the Barcelona Congress became the scene of much animated discussion about what the United States could do to regain some of its scientific prestige. While manned spaceflight and Moon landings were widely speculated about, many still harboured doubts about an American lead in space. One delegate, noticing that there were 23 American and five Soviet papers at the Congress, remarked that while the Americans talked a lot about spaceflight, the Russians just went ahead and did it!" (Clarke, 2007). 
Perhaps even more important, as Husen points out, was that education was not only tied to growth of the competitive power of nations, but also incorporated the notion of improvement of individual wellbeing: the opportunity to lead one's life freely and with one's own idea of what is worth living for. Men and women were supposed to gain an opportunity for self-realisation. However, it was only in the years of the next reconsideration of education in the form of "reports" that we witness at least two dimensions of the important breakthrough of meritocracy: individual and social, both of which restructure education in Western Europe (Husen, 1974). Which dimension prevailed at any one moment depended on the dominant social and political philosophy, or on the type of rationality prevalent in a specific society in a certain period: if the society was more liberal, its focus was more on the individual and his or her self-realisation, whereas in societies with a more developed collective component the use of talent was predominately related to the growing power of the national economy (for more on this, see Husen, 1974).

During the second wave of mass education, the type of educational rationality - and with it the approach to positioning the individual and the group in society - shifted for good from "social ascription to one based upon age, aptitude and ability" (Brown, 1997, p. 394). With the new rationality, the emphasis on talent and effort, together with individual achievement, came to the fore. This was supposed to outline a new educational, professional path, and even to change the role of citizens in societies in the second half of $2 \mathrm{O}^{\text {th }}$ century.

Everyone with a certain level of intelligence and a preparedness to invest effort in education should have equal access to public positions that demand demonstrable ability. It is thus assumed that education is capable of identifying and selecting talented and motivated individuals, and of providing education related to individual merit. At the same time, this ensures a comparative advantage to nations that invest in education for everyone, relative to nations that are unable or unwilling to invest in activating as many of their citizens as possible. In other words: equal access to education, the liberalisation of education, opened the way to education meritocracy, which in turn brought hope to ever greater sections of the population. In addition, and probably equally importantly, it brought hope for fair selection independent of social origin.

8 In France, in the form of studies (Bourdieu \& Passeron, 1964; Peyre, 1959) demonstrating that there had not been enough progress in the area of social equality: Coleman's study proved that ethnic minorities do not have equal opportunities to reach high standards in education as the white majority; the Plowden Report, which was known for its endorsement of child-centred approaches to education, also exposed the problems of social inequalities. 


\section{Changes in the education structure of a nation as empirical proof of the power of education}

The widely opened doors of secondary education and the growing number of places in tertiary education brought previously unimaginable growth in the number of individuals graduating from both institutions. While even an important part of the $19^{\text {th }}$ century demand for universal basic education seemed like an illusion that was barely achievable, and it was upper-secondary education that brought social prestige and cultural capital, which one could validate in the form of a better job, in the 1960s and 1970s, one can already identify significant changes in this respect. More and more citizens with upper-secondary education, as well as a growing number continuing their education at tertiary level, seemed to be the new norm. Education became perceived as one of the safest and most necessary investments of individuals and nations. As Beck ascertains with regard to post-WWII Germany, it is credible to speak of the "elevator effect" in education (Beck, 2001), in view of the upward social mobility of significant segments of the population (see Beck, 1991; Beck \& Beck-Gernsheim, 2002).

A similar process can be perceived in other states of the Western world. Even in England, which is renowned for slow growth in the share of the population with higher education, data demonstrate that, for example, the mere $8.4 \%$ of children aged 11-18 attending education in 1938 increased to $30 \%$ in 1951 . The numbers increased correspondingly in higher education, from 69,000 students in 1938 to 215,000 in 1970, a threefold increase (Brown et al., 1997, p. 5).

Data show an increasing proportion of the population completing high school and college in the USA. In 1910, 13.5\% of the population aged 25 and over had completed high school and only $2.7 \%$ had gained a BA degree or higher, but by 1940 the figures had increased to $24.5 \%$ and $4.6 \%$, respectively. An impressive rise of educated youth is evident in data after 1960. In 1960, the proportion of the generation enrolled in tertiary education was already $45.1 \%$, but only ten years later it had reached an impressive 51.8\% (McNamee \& Miller, 2009, p. 109-110).

The trend can be observed in France as well, where Duru-Bellat (2000) writes that the $2 \mathrm{O}^{\text {th }}$ century saw an immense rise in the level of education at all levels, while in the last 30 years there has been even more rapid growth in the number of degrees completed. The author supports her claims with statistical data: "the percentage of those with baccalaureat increased from $20 \%$ in 1966 to $40 \%$ in 1986 and reached 68\% in 1996" (ibid., p. 334). The statistics presented demonstrate that the share of the population in education was stable until 1939, while an important rise can be ascertained for the generations born between 1939 and 1948, i.e., the generations with more open access to secondary education after WWII. This 
group is followed by age cohorts with an even greater rise: those born after 1954 . For the generations born after 1959, the author claims there was universal access to upper-secondary education (see ibid.). Yet the picture in France becomes far more complex when we take into account education trajectories in relation to gender and social origin, for which France is also renowned. Starting with the INED studies in the 1950s, observers became increasingly sensitive to social differences, with the first study demonstrating that the reproduction of social inequalities continued to take place despite immensely improved access to education. ${ }^{9}$

\section{Education, equality and equity in the Socialist Republic of Yugoslavia: Slovenia}

One question arises on the background presented above: What happened in the same period in socialist countries? In order to answer this question, one would need access to thorough research, but such a task is at present beyond our capabilities and ambitions. In what follows, we will therefore attempt only a preliminary investigation of one particular segment of the developments in one of the then republics of Yugoslavia, the Socialist Republic of Slovenia, which is today an independent state with just over 20 years of statehood as the Republic of Slovenia.

For Slovenia, the last classical census (2002) and all of the data available for the subsequent years demonstrate that we are witnessing a continuing new wave of educational upward mobility of new generations. Beck's educational elevator is again transferring generations of the population upward after a telling delay in respect to the transfers that took place in the liberal democracies of developed democracies in the 1980s and 1990s. (see Gaber, 2006; Gaber \& Marjanovič Umek, 2009). The last wave - a prolonged wave due to the mistakes in creating education policy in the former Yugoslavia and the late decision to reform this policy, at the beginning of the 1990s - started around the mid 1990s of the previous century (see ibid.).

Nonetheless, within the aforementioned framework of the prevailing type of post-war rationality (Foucault, 2009; Weber, 1905/2002, 1978) in the first three decades after 1945, we can in Slovenia - as an example of a socialist country - also ascertain an emphasised orientation towards an approach to structuring education that was intended to bring equality through education. The first wave of education mobility is embedded in the socialist ideology of

9 The percentages of the population with baccalaureat had increased to $77.2 \%$ by June 2015 . Retrieved 6.11.2015 from http://www.education.gouv.fr/cid56455/le-baccalaureat-2015-session-dejuin.html\&xtmc $=$ nombredediplome20142015\&xtnp $=1 \& x t c r=20$. 
more education for all. Thus, while Slovenia started with a population that was far from optimal and competitive in terms of education (see Table 1), it is evident from the 1961 census that an important share of the new generation had achieved a higher degree of education than the previous generation.

Not surprisingly, we believe this was due to the proclaimed socialist orientation of the country. Yet there is one element in relation to the post-war shifts in rationalities all around Europe that could also be productive to explore. The question we have in mind is that of different approaches to the search for more equality in a particular society. More specifically, the question related to the productiveness vs. counter-productiveness of particular approaches to the reduction of social inequalities/inequities reproduced in part through education. Our colleague Medveš (2015) may be correct in claiming that Socialist Yugoslavia, with the exaggerated stress on the unified school (enotna šola) in its post-WWII education reforms, overstepped the line between relying on comprehensive education as one of the important mechanisms to increase opportunities for more equal and just education, on the one hand, and the myth of the almighty unified school that would erase social inequalities, especially class inequalities, on the other. It may be that, with this mythologisation of the power of the unified school in the search for mechanisms that would enable a reduction in the gap between the educational attainment of working class children and those of middle class parents, yet another socialist project was forfeited to the illusion of the power that is supposed to rest in so-called simple equality (see Sen 1992; Walzer, 1983). Even more: with its radical approach to the eradication of inequalities, socialist policy in the then Yugoslavia paradoxically reduced opportunities for greater equality, and even more so for more equitable education, in the realms of a project of socialist modernisation that was risky in a number of aspects.

At the same time, the Slovenian case is a clear signal that, in the period of the creation of the modern welfare state and in parallel with endeavours to raise the level of equality in modern societies with the help of education, at least in one state in the socialist block a structured discussion took place concerning the need for a scientific approach to education reform, not only in terms of how such a reform should be put in place, but also about its aims. ${ }^{10}$ One of these aims

10 Among others, this question was addressed by the doyen of Slovenian pedagogy, Prof. Schmidt. While criticising capitalist pedagogy as a reduction to the "technology and question of means", he was also critical of the fact that it was not possible to find a "methodology of school reform in socialist pedagogy" either (Schmidt, 1966/1982, 97). He was particularly concerned by the fact that the "very conceptualisation of the process of the reform is not in the focus of methodological studies" (ibid.). He was thus horrified that, in 1965, the authorities in Yugoslavia planned to prolong unified education for another two years, extending it to ten years, without "asking any institution competent in sociology, psychology or pedagogy to help with research" (ibid., p. 98). He adds: "this is also not acceptable while it is going on in a country declaring that its development is scientifically founded, and in a time when capitalist Sweden has inaugurated its reforms after years of thorough research, experiments and discussions"(ibid.). 
was the attempt by the authorities to achieve equality by prolonging unified education (see Schmidt, 1966/1982). The question even arises as to whether it is possible that the mythologisation of the power of unified education could actually be counterproductive for society, or, as formulated by Schmidt, we can wander around while we have "ground under our feet and we experience the sad destiny of 'those wanting to search for the betterment of mankind' who remained detached from reality in the world of ideas, without knowing the mechanisms for their realisation" (Schmidt , 1966/1982, p. 100) ${ }^{11}$.

In the years that France, Great Britain, Nordic countries, the USA and elsewhere witnessed studies and reports explaining that wider access to education alone is far from enough to achieve equality in terms of education attainment, and produced research examining possible additional mechanisms that should be put in place to reduce the reproductive power of social inequalities, ${ }^{12}$ the focus of education reforms in Slovenia, as well as in other republics of

11 Although Schmidt was very bitter, he was familiar with the studies of his colleagues analysing the results of the reform from 1958 and knew their proposals for improvements, which looked promising in terms of increasing the chances for actual equity in education. One year before he published his article, his colleague from the Department of Pedagogy, Prof. Strmčnik, had written a study that, in a relatively precisely and evidence-based way (data were collected by the National Office for the Progress of Education), analysed the main reasons for the failures in the realisation of the idea of a Yugoslav type of comprehensive education. Strmčnik presented reform as a realisation of "people's striving for equal basic education" (1965, p. 78). Based on data, he warns that it is not possible to establish equality in education while we "have incredibly unequally qualified teachers in different municipalities and in different schools" (ibid., p. 82). According to him, poorly educated and badly paid teachers - resulting in a lack of teachers for some key subject areas in remote municipalities and in less developed parts of the country - in combination with unacceptable arrangements making it possible to progress from one grade to the next without a pass grade in even one subject, place education reform in the position of having primarily preached the idea of equal conditions for the basic education of all the pupils, "but in reality having done everything to ensure its failure" (ibid. p. 92). He concludes with a warning that in preventing it "we have succeeded" (ibid.). Writing in line with the findings in the Coleman Report, and with other studies in France, Great Britain, etc., he points to overly large differences in the basic conditions for education in rural and urban areas, as well as differences between developed and poorly developed parts of the country, stating that it would be possible to aim for equality of basic education as the basis for further education and fair opportunities in life. His conclusion was radical for the time and place in it was which published: a "school of high quality" is all that is needed to reduce inequalities, and that we do not need a school "that accommodates pupils to the (...) relatively undeveloped environment, but one that can prepare them for the elimination of such a situation" (ibid., p. 93). Relatively similar ideas, this time dealing with the implementation and required improvements of school curricula, can be found in another study, again prepared by the National Office for the Progress of Education and its manager Iva Šegula. Schmidt was familiar with both studies, as well as a number of others that were not used in planning education reforms.

12 See the warning of Bourdieu and Passeron related to the omission of the symbolic violence inherent in the celebration of the school as an institution that enables us to acquire knowledge if we are talented and conscientious. See also Bernstein pointing to the need for reflection on the inner logic of the school as a mechanism that - by definition and not only due to the external pressure of the ruling class, the economy, etc. - ensures the elements that form part of the mechanism of the educational reproduction of social inequality, from the language used to the types of pedagogical approaches employed (see Bernstein, 2003; Bourdieu and Passeron 1964, 1970). 
Yugoslavia, was the idea of the elimination of inequality between the working class (and peasants) and the bourgeoisie, and with this the idea of the elimination of the difference between manual and intellectual labour (see Humek, 1955). In parallel with this, one of the important elements that was intention to bring equality in society was the enrolment of women in education. After the war, women gained voting rights, equal pay for equal work was enforced by law, and women gradually entered professions that were traditionally the reserve of men (see Gabrič, 2009; Antić-Gaber, 2015), such as the academic world, research and politics, even beginning to occupy management positions. In this area, one should be aware that, despite equality in political life being constitutionally granted, this was far from achieved (Jogan, 2001, p. 57). On the other hand, equal participation of women and men in education was not only granted but also achieved faster. In 1946, the Constitution granted equal rights to women in education ${ }^{13}$ in Article 38 . This was in line with the aforementioned idea of equality that underlined all of the approaches to education reforms in Yugoslavia. At first, the approach brought important investments and results even in the first decade after WWII, in terms of new schools being constructed throughout the country, as well as in the number of young people, both male and female, enrolled in secondary and tertiary education (see Gabrič, 2009). The next step was the General Law on Education in 1958, which forwarded the aforementioned idea of a thorough general education for all of those in Yugoslavia who, prior to the war, had been poorly educated. While an inclusive approach was needed, and was beneficial in particular for those republics with a high level of illiteracy, the other part of the idea - the part aimed at simple equality in the nation as a whole (see Walzer, 1983) - was far less beneficial. Moreover, this was the case despite the guiding idea that aimed for the elimination of inequalities in the nation, thus leading to equality between different citizens. The problems started with the first idea: everyone should have access to education of equal quality, followed by access to schools at another level. As demonstrated above, the conditions in schools were far from equal, with problems ranging from teacher competencies to equipment, furniture, the subjects actually taught, etc. It was therefore unrealistic to expect a system according to which the results achieved in the previous level of education should not matter on entrance to the next level, which was an important reason for inequalities in results remaining. 


\section{Problems with the idea of simple equality}

While Yugoslavia, together with Nordic countries, ${ }^{14}$ was among the first in Europe to inaugurate comprehensive education and take an important step towards possible justice in education, the naïve idea of simple equality destroyed the majority of the positive effects already achieved when authorities began to dismantle the rare but still functioning schools that had previously prepared pupils for further education at the level of secondary education. The fact was that "unified basic education" for everyone was not able to solve the problem that the League of Communists perceived as crucial: that again and again more children from middle class families in which parents had a better education entered grammar school (gimnazija) than children of working class and peasant parents. Unfortunately, the important idea of the 1958 reform, as well as the inevitable subsequent reform, was that intellectuals are not supportive of the project of socialism, and that overly demanding general education is particularly dangerous for its future. On this background, the authorities decided to, as soon as possible, eliminate an element from the logic of education that is inherent to education and had, at the same time, become even more prominent in education in Western democracies: the meritocratic principle. The idea of equal education for all and access for all at all levels and kinds of education ${ }^{15}$ became the logic firmly defended in the fear that the meritocratic logic would continue to reproduce the class differences that the authorities had been determined to eradicate. One representative of the League of Communists thus explained what the direction of the development of education should be in order for it to remain in line with the programme of the communist party, explicitly putting aside the idea of existentialism that had then become modern.

14 Nordic countries inaugurated comprehensive education under the influence of the philosophy of the welfare state and equality. Sweden took the first steps in this direction as early as in 1949, and implemented it in the full form of nine-year school in 1972, when they abolished other forms of compulsory education that had been on offer until then. Other Nordic states followed with some delay and additional caution. Antikainen points to the fact that in "the 1960 s and 1970s, compulsory education in all Nordic countries was extended to nine years, and the comprehensive model was adopted as the starting point of developing the whole education system (...)" (Antikainen, 2006, p. 230). Characterising the model as Nordic, he describes it as an "attempt to construct a national education system on the foundation of specific local values and practices, but at the same time subject to international conditions and influences, and even as an internationally influential example (1). Equity, participation and welfare state have been known as the major socio-political attributes of the Nordic model. The fourth attribute might be held to be progressiveness either as realization of a search for new, unprejudiced solutions, or at least as an image and myth associated with Scandinavian culture" (ibid., p. 229).

15 They went as far as legislating the possibility of progressing to the next grade with just one non-pass grade, despite the fact that experts warned that it could most damage those who were supposed to benefit from the mechanism (see Strmčnik, 1965; 1967). 
In the period in which Western democracies shifted their education to the search for education that would enable each of their citizens to realise his/ her entire potential with as much of effort he or she was ready to invest, socialist Yugoslavia - with a point of departure that was, in principle, the same, i.e., the optimal development of the potential of each and every individual - was blinded by a fear of the middle class and by efforts to enable each citizen to achieve at least a basic general education within the framework of unified compulsory education. It therefore ignored the need to allow for differences in the interests and potentials of children entering education, and above all overlooked the need for additional support for those from a less supportive environment, enabling them to reach standards that were far more accessible to children with a more educationally supportive home environment.

However, instead of searching to mechanisms that would support the aforementioned population in their efforts to achieve better results, the authorities decided for prevent those from more supportive environments to develop their talents, or to have an opportunity to develop them. From the blind spot or mythologisation of the power of unified education as the promoter of equality in society, the idea emerged of abolishing grammar school, as the supposed origin of the evil of inequality. Presentations of the evil reached tragicomic dimensions, which unfortunately had concrete practical consequences for the education system and for the knowledge achieved individually, at precisely the time when this knowledge was becoming more and more important for the nation.

One of the fierce proponents of abolition painted the grammar school as a "typically bourgeois school. (...) While students in them are put in unnatural life conditions and while they do not see the practical use of the results of their learning, they learn insincerity, hypocrisy, flattery, lack of character, cheating, etc. That is why moral education in such a school is suspicious. (...) And there also lies the reason why students of grammar schools live at the expense of the community" (quoted in Gabrič, 2006, p. 68). In all of this, it is telling that the author of these words was the director of a two-year post-secondary pedagogical school in Belgrade. In addition - to be even clearer - he divided schools into two groups: those whose pupils are educated to exploit, and those whose pupils are educated to be exploited. For him, it was obvious to which group grammar schools belonged.

There is no need to emphasise the fact that the counterarguments of those claiming that grammar school, as a high quality institution, is a must for tertiary education at the university were, in such an anti-intellectualism atmosphere, ignored. One of the forms this took was formulated by Boris Ziherl when describing and judging the stance of a teacher during public discussion surrounding 
the "Boštanj scandal": "The 'Boštanj scandal' demonstrated that our organisation, our forums of power, are taken by reaction, and that in our circles the widespread opinion is that questions of culture are questions that concern only the consecrated ones, that is, only experts, and that these questions are not for those representing the people and their will" (Gabrič 2006, p. 47).

\section{Concluding remarks}

Equality that at the level of secondary education acquired the form of the abolition of a more demanding programme, at the point of transition to tertiary education took the form of the abolition of entrance examinations, and in the field of education institution management produced the self-management of schools by school boards, the majority of whose members were poorly educated, was destined to reproduce inequalities (see Gabrič, 2006, p. 41). ${ }^{16}$ Paradoxically, in Slovenia, after the formal abolition of grammar school education, experts, in collaboration with some sections of the authorities, found a way to maintain the spirit of the previous elite secondary education through various programmes of secondary education. These then acquired names - science secondary education, social sciences and languages, general culture and secondary education for pedagogical professions - and although schools lost their original names, it was obvious that the Bežigrad Grammar School opted for an elite science programme of secondary education and even retained a sufficient number of optional subjects in its curricula to maintain a solid level of knowledge of social sciences and humanities. The same is true for what is now the second Maribor Grammar School, the social science and languages programme at today's classical Poljane Grammar School, and a number of others in larger cities around the country. We all knew that, despite the official demand for each programme to prepare students for work, the programmes were more than adequate to prepare for university studies. The situation was similar, albeit less clear, in some places in other republics of the then Yugoslavia. Nonetheless, the damage caused by anti-intellectualism was significant: thousands of lost graduates in the decisive years of the educational explosion in other countries in Europe.

16 "Also in the years after new Law, it was frequently the case that school boards dealt with questions of a pedagogical nature that were previously in the jurisdiction of teachers. Thus, in a number of cases, important expert questions were decided by lay people, while in the 1955/1956 school year more than three quarters of the places in school boards were occupied by members who had finished their education after the compulsory eight years. (...) even in the boards of grammar schools and of lower professional education schools their share was over $60 \%$, while the structure was far better in the school boards of colleges of education" (Gabrič, 2009, p. 41). 


\section{Sources and literature}

Antikainen, A. (2006). In search of the Nordic model in education. Manuscript for Scandinavian Journal of Educational Research, 50(3), 229-243.

Beck, U. (1991). Risk Society. Towards a New Modernity. London: Sage.

Beck, U. \& Beck-Gernsheim, E. (2002). Individualization. London: Sage.

Bernstein, B. (2003). Class Codes and Control IV. New York: Routledge.

Bourdieu, P., \& Passeron, J.-C. (1964/1979). The Inheritors. Chicago: UCP.

Bourdieu, P., \& Passeron, J-C. (1970/1990). Reproduction in Education, Society and Culture. London: Sage.

Bourdieu, P. (1989). Social Space and Symbolic Power. Sociological Theory, 7(1), 14-25.

Brown, P. (1997). The “Third Wave": Education and the ideology of parentocracy. In A. H. Halsey,

H. Lauder, P. Brown, \& A. S. Wells (Eds.), Education: Culture, economy, and society (pp. 393-408).

Oxford: Oxford University Press.

Brown, P., Halsey, A.H., Lauder, H., \& Stuart Wells, A. (1997). The Transformation of Education and Society: An Introduction. In A. H. Halsey, H. Lauder, P. Brown \& A. S. Wells (Eds.), Education:

Culture, economy, and society (pp. 1-44). Oxford: Oxford University Press.

Duru-Bellat, M. (2000). Social inequalities in the French education system: the joint effect of individual and contextual factor. Journal of Educational Policy, 15(1), 33-40.

Esping-Andersen, G. (1996). The Three Worlds of Welfare Capitalism. London: Polity Press.

Foucault, M. (2009). Security, Territory, Population. Hampshire: Palgrave Macmillan.

Gaber, S. (2006). Edukacija, socialna promocija in »dedovanje« izobrazbe. Sodobna pedagogika. 57, special edition, 42-53.

Gabrič, A. (2006). Šolska reforma 1953-1963. Ljubljana: Inštitut za novejšo zgodovino.

Husen, T. (1974). Talent, equality and meritocracy. The Hague: Martinus Nijhoff.

Medveš, Z. (2006). Upoštevanje drugačnosti - korak k šoli enakih možnosti. Sodobna pedagogika, 57, special edition, $10-24$.

Medveš, Z. (2015). Socialist pedagogy: Caught between the myth of the fairness of the unified school and cultural hegemony. Journal of Contemporary Educational Studies, 66(2), 14-40.

Meyer, J. W. (1977). The Effects of Education as an Institution. American Journal of Sociology, 83(1), $55-77$.

McNamee, S. J. \& Miller, R. K. Jr. (2009). The meritocracy myth. Lanham: Rowman and Littlefield Publishers, Inc.

National Defence Education Act (NDEA). (2015). In Encyclopædia Britannica. Retrieved 6.11.2015 from http://www.britannica.com/topic/National-Defense-Education-Act.

Peyre, C. (1959). L’origine sociale des élèves de l'enseignement secondaire en France. In Ecole et société. Recherches de sociologie du travail publiées sous la direction de Pierre NAVILLE, 5. Paris, Librairie Marcel Rivière.

Piketty, T. (2014). Capital in the Twenty-First Century. Harvard: Belknap Press. 
Schmidt, V. (1966/1982). Metodologija šolske reforme. In Socialistična pedagogika med etatizmom in samoupravljanjem. Ljubljana: DDU-Univerzum.

Schmidt, V. (1958). Povojni razvoj, sedanje stanje in perspektive pedagoške znanosti na Slovenskem.

Sodobna pedagogika, 9(9), 227-237.

Sen, A. (1992). Inequality Reexamined. New York: Clarendon Press.

Strmčnik, F. (1965). Enotna osnovna šola je bistveni element socialističnih družbenih odnosov.

Sodobna pedagogika, 16(3-4), 77-98.

Strmčnik, F. (1967). Kaj ovira hitrejši razvoj osnovne šole. Sodobna pedagogika, 18(5-6), 137-158.

Strmčnik, F. (2013), Prof. Gustav Šilih, vreden pedagoškega spomina. Sodobna pedagogika, 64(3), 94-97.

SORS (2001). Popisi na Slovenskem 1948-1991; Popis 2002. Ljubljana: SURS.

Šegula, I. (1964). Učni načrt osnovne šole v teoriji in praksi. Rezultati petletnega preizkusa. Ljubljana: ZNŠ.

Troger, V. (2002). Bourdieu et lécole: la démocratisation désenchantée. SH - special edition on Bourdieu, 16-23.

Vigotski, L.S. (1934/2010). Mišljenje in govor. Ljubljana: Pedagoška fakulteta.

Walzer, J. (1983). Spheres of Justice, A Defence of Pluralism and Equality. US: Basic Books

Weber, M. (1946). Essays in Sociology. Trans. and ed. H.H. Gerth and C. Wright Mills. New York:

Oxford UP.

Weber, M. (1978). Economy and Society. Vol.1 in 2. Berkeley: University of California Press.

\section{Sources:}

Clarke, A. C. (2007). Remembering Sputnik: Sir Arthur C. Clarke. Retrieved 6.11.2015 from http:// spectrum.ieee.org/aerospace/space-flight/remembering-sputnik-sir-arthur-c-clarke. Education gouv.fr. Retrieved 6.11.2015 from http://www.education.gouv.fr/cid56455/le-baccalaureat2015-session-de-juin.html\&xtmc=nombredediplome20142015\&xtnp=1\&xtcr=20.

EU (2020). Tertiary education attainment in 2020. Retrieved 6.11.2015 from http://ec.europa.eu/ europe2020/pdf/themes/2015/tertiary_education_attainment.pdf. 


\section{Biographical note}

Veronika TAŠner, $\mathrm{PhD}$, is an Assistant for the Sociology of Education at the Faculty of Education, University of Ljubljana. Her work involves research into meritocracy, equality and inequality in education, private education, and gender and education. She has participated in various research projects on the topic of education and its justice and future. She is the author of several articles and chapters in the areas in which she research in Slovene and foreign scientific journals and monographs.

Slavko Gaber, PhD, is an Associate Professor of Sociology at the Faculty of Education, University of Ljubljana. He lectures in Sociology of Education, An Introduction to Education Policies, Sociology of the Family, and EPTE Society, Culture and Education. His area of research and publishing comprises relations between school, society, democracy, equality and justice. 


\section{Appendix}

Table 1: Population aged 15 and more by education

\begin{tabular}{|c|c|c|c|c|c|c|c|c|c|}
\hline \multirow{2}{*}{$\begin{array}{l}\text { Izobrazba / } \\
\text { Education }\end{array}$} & \multicolumn{4}{|c|}{ Število / Number } & \multicolumn{4}{|c|}{ Delež (\%) / Share (\%) } & \multirow{2}{*}{$\begin{array}{r}\text { Izobrazba / } \\
\text { Education }\end{array}$} \\
\hline & 1961 & 1971 & 1981 & 1991 & 1961 & 1971 & 1981 & 1991 & \\
\hline SKUPAJ & 1156387 & 1311225 & 1457281 & 1156162 & 100 & 100 & 100 & 100 & TOTAL \\
\hline $\begin{array}{l}\text { Brez šolske } \\
\text { izobrazbe in } \\
\text { končani 1-3 } \\
\text { razredi OŠ }\end{array}$ & 89325 & 60337 & 51970 & 27719 & 7.7 & 4.6 & 3.6 & 1.8 & $\begin{array}{r}\text { No school- } \\
\text { ing and 1-3 } \\
\text { elementary } \\
\text { school grades }\end{array}$ \\
\hline $\begin{array}{l}\text { Končani 4-7 } \\
\text { razredi OŠ }\end{array}$ & 609700 & 331423 & 326106 & 238885 & 52.7 & 25.3 & 22.4 & 15.3 & $\begin{array}{r}\text { 4-7 elemen- } \\
\text { tary school } \\
\text { grades }\end{array}$ \\
\hline Osnovna šola & 227116 & 536857 & 473982 & 466782 & 19.6 & 40.9 & 32.5 & 29.9 & $\begin{array}{r}\text { Elementary } \\
\text { school }\end{array}$ \\
\hline $\begin{array}{l}\text { Šole za KV in } \\
\text { VKV delavce }\end{array}$ & 151348 & 230023 & 320784 & 303198 & 13.1 & 17.5 & 22.0 & 24.4 & $\begin{array}{r}\text { Schools for } \\
\text { skiled and } \\
\text { highly skiled } \\
\text { workers }\end{array}$ \\
\hline $\begin{array}{l}\text { Ostale sred- } \\
\text { nje šole }\end{array}$ & 53087 & 102289 & 182566 & 365960 & 4.6 & 7.8 & 12.5 & 19.4 & $\begin{array}{r}\text { Other } \\
\text { secondary } \\
\text { schools }\end{array}$ \\
\hline $\begin{array}{l}\text { Višje, } \\
\text { visoke šole in } \\
\text { fakultete }\end{array}$ & 20383 & 43361 & 89973 & 138012 & 1.8 & 3.3 & 5.9 & 8.8 & $\begin{array}{r}\text { Non-univer- } \\
\text { sity colleges } \\
\text { and universi- } \\
\text { ties }\end{array}$ \\
\hline Neznano & 5401 & 6935 & 11837 & 21072 & 0.5 & 0.5 & 1.1 & 1.4 & Unknown \\
\hline
\end{tabular}

Statistical Office of the Republic Slovenia (SORS 2001)

For comparison and evidence-based evaluation of the progress in the share of the educated in Slovenia, we add some data from the 1953 census and censuses from the 21st century.

While the methodology applied for data collection and calculation differs for the 1953 census and subsequent censuses, it is possible to calculate and compare some data:

The share of people with more than secondary education grew from only $0.09 \%$ in 1953 to $8.8 \%$ in 1991 (still in socialism), rising to $17.4 \%$ in 2011 . The share of the population completing technical, general upper-secondary education (four-year upper-secondary education) rose from $1.5 \%$ of the population aged 15 years or more in 1948 to $19.4 \%$ at the end of socialism in 1991, and to $30.2 \%$ in 2011.

Concerning our thesis regarding the late second education elevator effect in Slovenia, it is telling that, in 2014, Slovenia had already reached its own target and the EU target, which is $40 \%$ or more of those aged $30-34$ years 
completing the tertiary level of education. Slovenia reached the target despite the fact that in 2000 only $18.5 \%$ of those in the same age cohort completed tertiary education.

\begin{tabular}{rrrrrrrr}
\hline & 2000 & 2010 & 2011 & 2012 & 2013 & 2014 & Target \\
\hline Slovenia & $18.5 \%$ & $34.8 \%$ & $37.9 \%$ & $39.2 \%$ & $40.1 \%$ & $41.0 \%$ & $40.0 \%$ \\
\hline
\end{tabular}

(see: EU (2020))

Table 2: Population aged 15 or more by educational attainment and gender, Slovenia, 2002 Census and 1 January 2011

\begin{tabular}{lcccccc}
\hline & \multicolumn{3}{c}{1 January 2011 } & \multicolumn{3}{c}{ 2002 Census } \\
\cline { 2 - 7 } & Total & Men & Women & Total & Men & Women \\
\hline Total & 100.0 & 100.0 & 100.0 & 100.0 & 100.0 & 100.0 \\
\hline No education & 0.3 & 0.2 & 0.4 & 0.7 & 0.5 & 0.8 \\
Incomplete basic & 4.1 & 3.2 & 4.9 & 6.3 & 5.3 & 7.2 \\
Basic & 24.7 & 21.2 & 28.2 & 26.1 & 21.1 & 30.8 \\
$\begin{array}{l}\text { Short-term vocational upper- } \\
\text { secondary }\end{array}$ & 1.4 & 1.5 & 1.3 & 4.2 & 5.3 & 3.3 \\
$\begin{array}{l}\text { Vocational upper-secondary } \\
\text { Technical, general upper-secondary }\end{array}$ & 21.7 & 28.5 & 15.1 & 22.9 & 29.6 & 16.7 \\
$\begin{array}{l}\text { Short-term higher (former), higher } \\
\text { vocational }\end{array}$ & 30.2 & 30.0 & 30.4 & 26.9 & 25.7 & 27.9 \\
$\begin{array}{l}\text { 1st cycle of higher, professional } \\
\text { higher (former), etc. }\end{array}$ & 3.8 & 4.3 & 5.3 & 5.1 & 4.5 & 5.6 \\
$\begin{array}{l}\text { 2nd cycle of higher, professional } \\
\text { higher (former), etc. }\end{array}$ & 8.1 & 7.1 & 9.1 & 6.4 & 6.4 & 6.3 \\
$\begin{array}{l}\text { "Magisterij" (Master) of science } \\
\text { (former), etc. }\end{array}$ & 0.8 & 0.9 & 0.8 & 0.7 & 0.8 & 0.6 \\
\begin{tabular}{l} 
Doctorate in science \\
\hline
\end{tabular} & 0.4 & 0.6 & 0.3 & 0.3 & 0.4 & 0.2 \\
\hline
\end{tabular}

(see: EU (2020)) 